\title{
Ecological-and-Social Responsibility of Coal Mining Companies
}

\author{
Sergey Kovalevsky ${ }^{1}$, Nikita Ravochkin ${ }^{2,}$, Vladimir Shchennikov ${ }^{3}$ \\ ${ }^{1}$ T.F. Gorbachev Kuzbass State Technical University, 650000Vesennyaya str., 28, Kemerovo, Russian \\ Federation \\ ${ }^{2}$ Kemerovo State Agricultural Institute, 650056 Markovtseva street 5, Kemerovo, Russian Federation \\ ${ }^{3}$ Kemerovo State University, 650000, Krasnaya str. 6, Kemerovo, Russian Federation
}

\begin{abstract}
Developing a modern view of social and environmental responsibility as a part of environmental policy and taking into account the specifics of coal industry, the article describes the obstacles on the way to its implementation in practice, the main reason of which is the weakness of ecologically oriented thinking. The study shows that Russian enterprises of the coal industry, despite their importance for the economy, are still not fully aware of the need to take into account the factors of their own impact on the environment. The environmental peculiarities of the coal industry enterprises of are determined. The styles of thinking of the management of coal companies during Soviet times and at the end of the twentieth century are traced, when Western standards of mineral resource extracting have not completely adopted yet. Ecological-and-social responsibility is understood by the authors as the highest level of environmental obligation to solve the primary ecological problems. In conclusion, the directions of implementing environmental initiatives are noted.
\end{abstract}

\section{Introduction}

As it is known, any miming and other industrial activity to a certain extent affects the environment, having a difference only in the scale of the impact. Of course, most often this influence is negative, which also does not contribute to raising the standard of living and preserving the conditions of existence in mining regions. Today there is a multiplication of the number of such the influencing factors: air, water, soil pollution, radiation.

Mining industry has the greatest impact on the ecological situation. Moreover, given that the attitude of man to environment has not fundamentally changed for centuries to the beginning of the twentieth century, it is quite logical that the modern ecological crisis has significantly changed natural resource miming communities to the problems of the environment. Considering the environmental aspect is only an element of mining enterprises' activity. It seems to us that under the dominance of an interdisciplinary paradigm, such problems must be solved not only in the ecological aspect, but also in expansion of the boundaries of ethical, economic, political, legal and scientific interpretations.

\footnotetext{
* Corresponding author: nickravochkin@mail.ru
} 
Thus, the formation of a responsible attitude to the environment is nothing but an integral condition for the successful development of mining industries. The environmentaland-legal discourse organized by national governments worldwide also notes this. So, for example, in the last ten years in the Russian Federation a lot of normative legal acts of various kinds have been adopted, in accordance with which environmental development of resource extracting industries is being realized.

The following is obvious: dynamic competitive advantages, including the ecological potential of the enterprise and the mining region itself, are of primary importance. In this regard, organizations of various industries, not only mining, are now required to organize their activities in such a way as to minimize the negative impact of internal processes on the environment. For what it is necessary to analyze the activity of mining enterprises and highlight the ecological aspects to prevent or minimize the negative impact.

Summarizing the problem, it should be noted that the unconscious consumption of natural resources by mining enterprises becomes an acute problem in a global scale. The enterprises of the coal industry, which are an integral part of the mining industry, perform a kind of activity that presents an increased environmental hazard. It follows that further growth in the natural resources consumption by these enterprises as a powerful component of the Russian economy will lead to the increase in production turnover and a pressure on resources [1]. It is also natural that this will negatively affect not only the state of the environment, but also it will rise the level of human wellbeing. In this regard, it is necessary to introduce corrective measures in the ecological responsible policy pursued by coal mining enterprises (ecologization), showing, a careful attitude towards nature, the environment and the planet.

\section{Materials and Methods}

In recent years, there has been a reorientation of business to sustainable economic development, one of which aspects is corporate social responsibility. In the classical approach of the corporate social responsibility given by A.B. Carroll implies economic, legal, ethical and philanthropic responsibility. These benefits are attributed to the possibility of increasing efficiency and competitiveness through the formation of sustainable relationships with employees, customers, creditors, investors, suppliers, government agencies and the media, reducing risks, improving business reputation, obtaining tax benefits, increasing the market capitalization of business and other similar factors [1].

Analyzing the possible irreversibility of the consequences of the consumer attitude to nature, Western mining business came to the need to identify its own functions and role in social development and interaction in the realities of the conflicting interests of various social actors. Following this idea, corporate ecological responsibility is the sum of voluntary investments by enterprises to solve problems of the negative impact on the environment and reduce tensions in society in order to avoid ecological crisis and to enhance the reputation effect [2].

The activity of modern enterprises influences environment and social processes due to the involvement of the business in its life through interaction with a number of interdependent stakeholders and organizations. Ecological-and-social responsibility becomes an important component of the corporate strategy of modern enterprises and mining companies [3]. It should be noted that with regard to the coal industry enterprises (by the way, as well as to a number of others), there are no unified notions about the essence and standards of not only sustainable development (most often there is primitivization), but also ecological-and-social responsibility of business. The similarity of approaches to clarifying these concepts is seen only in the fact that they all imply some 
responsibility of the enterprise to the nature as a whole, with which mining activities are connected [4].

Dynamics of globalization processes of the XXI century makes the world less predictable, bringing uncertainty and uncontrollability to the future. The most important problem of modern technogenic society is environmental risks. The nature of man presupposes the existence of a constant risk to human life. Awareness of the threat of death becomes an impetus to the creation of ecological ethics, ecological awareness, therefore the problems of ecology now primarily belong to men, and not just to the nature [5-6].

The transition to sustainable development is associated with global environmental problems, which makes us to pay attention to the seemingly not too relevant in comparison with the profit from mining [7]. We will clarify that by sustainable development we mean balanced, environmentally safe socio-economic growth without exhaustion of the natural and resource potential, which implies the strengthening of responsibility for all forms of activity that damage the natural environment. In Russia, the coal industry is one of the most real threats coming from industrial enterprises. Its functioning within the framework of current environmental standards and, most importantly, their representations will lead to the loss of the ability of the biosphere and its ecosystems to assimilate the effects of anthropogenic impacts on the environment.

\section{Results and Discussion}

The instability of the Russian economy, marked by a number of tendencies, mainly affects negatively the activity of enterprises in the real sector. In modern Russia, there is a trend, indicating a deterioration in the environmental situation in the coal-mining regions. This has a negative impact on the demographic situation, the state of the workforce, the health of the nation, and thus on the prospects for progress and modernization of the country as a whole.

Not only these, but also the strengthening of globalization trends, entails the need to change the thinking of the coal enterprises management. Ecologically responsible business plays an important role in the protection of the environment $[8,9]$. This is manifested in the fact that the foremost managers take an increasingly active environmental position and not only comply with environmental legislation, but also come up with initiatives aimed at tightening environmental standards. To achieve not only economically, but also ecologically significant activities, the enterprises of the coal industry are forced their adaptation to a qualitative change in requirements. Problems of social and ecological responsibility of the coal industry arise, among others, due to the lack of clearly articulated, unambiguously interpreted principles, unpredictability and non-transparency in the adoption and implementation of regulatory decisions. Thus, social and environmental responsibility, its articulation and broadcasting is the key to increasing competitiveness among Russian and foreign coal mining enterprises. An additional target for socially and ecologically responsible activities of coal industry enterprises in mining regions is not only the reduction of pollution, preventive measures of its minimizing, improving the provision of environmental information, but also the formation and development of a comfortable environment for human life. At the same time, the characteristics that determine the comfort of both the internal and external environment of human habitation are of great importance, which is possible through, for example, the active involvement of mining enterprises and public organizations in environmental projects.

In the domestic coal industry, the rejection of exclusively pragmatically oriented pursuit of profit (1990s) or even Soviet ideas (the consumer attitude to exhaustible resources) should occur through the re-orientation of the natural resources markets and through the activities of mining enterprises to build the strategy for cooperation with stakeholders to 
receive ecological recognition in the future. But unfortunately now the environmental problems are considered mainly from a sanitary point of view, without change of thinking to the ecological-and-social responsibility.

The failure of Western approaches has allowed owners and management of coal enterprises to prefer to pay fines for environmental pollution, rather than formulate responsible behavior [7]. In the long-term period, instead of one-time and non-systemically implemented ecological projects, the change of thinking should become the core of the new ecological thinking of the coal companies' management in conjunction with awareness of their real harm to nature. Unfortunately, as long as such thinking is not very actively perceived in Russian coal business, only in case of a change in the style of doing business the global problem of the ecological habitat preservation can be successfully solved.

In order to achieve the goals of ecologically and socially oriented development of mining industry, the system of institutions should cover all participants in all stages of the functioning of the coal enterprises with all stakeholders. Their interests intersect in the sphere of environment management and protection, and are implemented through state environmental regulation and through ecological responsibility of enterprises. Therefore, coal mining enterprises face serious demands and expectations from all stakeholder groups - from shareholders and customers to the society and the state [10]. We note here the fact that coal mining disturbs, for example, the landscape or produces the volume of the maximum permissible load on the atmosphere or the lithosphere, which is much larger than the standards adopted, at least by the officials. Only through repeated protests of local communities, the state is able to take more stringent measures for environmental damage. Thus, the enterprises of the coal industry should realize the urgency of creating additional incentives (the use of high technologies, the introduction of their own pollution standards, which are tougher than the state's ones), which reduce harm from mining processes, when implementing the paradigm of ecological-and-social responsibility.

If ecological responsibility is conditioned by the requirements of regulatory and legislative acts of mandatory application, then coal mining enterprises should comply with mandatory environmental requirements and standards. In addition, management should switch to proactive activities that cover the coal industry in all its multiple links. Coal mining enterprises and companies must go beyond the regulatory and legislative framework and initiate the adoption of additional, increased environmental requirements, which should be met by the mining activities of enterprises and their results (products, works). The ecologization of thinking requires not only the actions of coal enterprises management, but also the efforts of many specialists from different sectors, politicians, public persons. And until they reconsider their positions, they will not refuse from technocratic positions and collective efforts will lead to the first success.

Growing attention to global environmental and humanitarian problems on the part of society and the state leads to the fact that the activities of companies in the field of sustainable development will be under increasing scrutiny, and the criteria for assessing performance in this area will be constantly tightened. The ecological-and-social responsibility from the standpoint of interdisciplinarity must be concerned as the highest level of social responsibility, as a response to actual problems caused by changes in the ecological conditions of human life [11].

Changing the thinking to ecologically responsible models the appropriate behavior that facilitates the expansion of its partner and client base, which is directly related to business development, since both authorities and mining companies in developed countries prefer to deal with the companies that care for environment protection, contributing to it reputational capital. In addition, not only paying attention to the social, but also to the ecological side of mining, we note that the coal industry enterprises that are guided by the ecological 
responsibility in business practice, create more effective models of competitiveness, and therefore receive more profit.

\section{Conclusion}

Aspirations for sustainable and safe development of mining territories and the entire coal industry are the necessary imperative for the management of the modern domestic coal industry enterprises. This is explained by the fact that it is connected with the increased environmental load, and it is supposed to achieve and consistently maintain a balance between the economic, environmental and social aspects of coal mining.

In Russian coal mining regions, it is still possible to implement the following ecological measures: reduction of pollution of atmosphere, water resources, initiation of regional-andcorporative environmental standards, introduction of resource-saving technologies, utilization and recycling of mining waste, restoration of disturbed lands, etc., etc. Thus, the economic situation demonstrates that the modern coal business in the case of integrative but not isolationist tendencies cannot ignore international market demand. Accordingly, the coal industry enterprises should conduct their activities taking into account the latest requirements to the environmental component of production, as well as forecast its development and anticipate requirements through strict limitation of environmental polluting effects.

An indispensable condition for ecological-and-social responsibility development of the coal industry enterprises is the necessity of coincidence of the vectors for the development of the economy, society and nature, but in no way their displacement into the plane of antagonistic relations. It is obvious that the introduction of the provisions of ecological-andsocial responsibility in the thinking of management of Russian coal companies in the near future will become the norm of doing business.

\section{References}

1. A. B. Carroll, Business and Society, 38:3, 268-295 (1999).

2. B. J. Christensen, C. Kowalczyk, Globalization: Strategies and Effects (SpringerVerlag, Berlin, 2017.)

3. H. Cuadra-Montiel, Globalization: Approaches to Diversity (InTeOp, Amsterdsm, 2012)

4. I. Dzeraviaha, Ecological Economics, 148, 15-21, (2018)

5. P. Enderwick, International Business Review, 27:2, 410-417 (2018)

6. S. Guifeng, S. Jianfei, Z. Li, J. Yufang, Journal of Accounting and Public Policy, 36:6, 417-428 (2017)

7. R. E. Hester, R. M. Harrison, Coal in the 21st century: energy needs, chemicals and environmental controls (Royal Society of Chemistry, London, 2018)

8. S. O. Idowu, M. Aluchna, The Dynamics of Corporate Social Responsibility: A Critical Approach to Theory and Practice (Springer, Berlin, 2016)

9. F. S. Nobre, D. Walker, R. J. Harris, Technological, Managerial and Organizational Core Competencies: Dynamic Innovation and Sustainable Development (IGI Global, London, 2011)

10. N. Ravochkin, V. Shchennikov, V. Syrov, E3S Web Conf., 21, 04017 (2017)

11. Ch. Walker-Said, D. J. Kelly, Corporate social responsibility? Human rights in the new global economy (The University of Chicago Press, Chicago, 2015) 